\title{
Hematological parameters in Ghanaian sickle cell disease patients
}

\author{
Charles Antwi-Boasiako' \\ Ivy Ekem² \\ Mubarak Abdul-Rahman ${ }^{3}$ \\ Frederika Sey ${ }^{4}$ \\ Alfred Doku ${ }^{5}$ \\ Bartholomew Dzudzor 6 \\ Gifty B Dankwah' \\ Kate Hagar Otu ${ }^{7}$ \\ John Ahenkorah ${ }^{8}$ \\ Robert Aryee'
}

'Department of Physiology, School of Biomedical and Allied Health

Sciences, University of Ghana, Accra,

Ghana; 'Department of Haematology,

School of Medical Sciences, College of

Health and Allied Sciences, University

of Cape Coast, Cape Coast, Ghana;

${ }^{3}$ Department of Pathology, School of

Biomedical and Allied Health Sciences,

University of Ghana, Accra, Ghana;

${ }^{4}$ Sickle Cell Clinic, Korle-Bu Teaching Hospital, Accra, Ghana; ${ }^{5}$ Department

of Internal Medicine, School of

Medicine and Dentistry, University

of Ghana, Accra, Ghana; ${ }^{6}$ Department

of Medical Biochemistry, School

of Biomedical and Allied Health

Sciences, University of Ghana, Accra,

Ghana; ${ }^{7}$ Department of Nursing and

Midwifery, Greenhills School of Health

Sciences, Accra, Ghana; ${ }^{8}$ Department

of Anatomy, School of Biomedical and

Allied Health Sciences, University of

Ghana, Accra, Ghana

Correspondence: Charles

Antwi-Boasiako

Department of Physiology, School of

Biomedical and Allied Health Sciences,

College of Health Sciences, University

of Ghana, PO Box DC 754, Dansoman,

Accra, Ghana

Email antwiboasiako@gmail.com
This article was published in the following Dove Press journal:

Journal of Blood Medicine

\begin{abstract}
Background: Effective treatment and management of sickle cell disease (SCD) has been a challenge in Africa over the years. Hematological parameters are very useful profiles in the effective management of the disease. However, there is scarcity of studies on the hematological parameters of SCD in Ghana. This study aimed at determining hematological parameters among SCD patients with vaso-occlusion, those in the steady state as well as healthy controls at a teaching hospital in Ghana.
\end{abstract}

Methodology: This was a cross-sectional study involving a total of 628 subjects, including $148 \mathrm{HbAA}$ controls, $208 \mathrm{HbSS}$ patients in steady state, $82 \mathrm{HbSC}$ patients in steady state, 156 HbSS patients in vaso-occlusive crises (VOC), and $34 \mathrm{HbSC}$ patients in VOC. Venous blood sample was collected from all study participants. A full blood count was done within 2 hours of collection, and hemoglobin ( $\mathrm{Hb}$ ) concentration, packed cell volume, red blood cell (RBC) concentration, mean corpuscular $\mathrm{Hb}$, mean cell volume, mean corpuscular $\mathrm{Hb}$ concentration, and white blood cells (WBC) and platelet (PLT) counts were recorded.

Results: WBC and PLT counts were significantly higher in both female and male patients with SCD, compared with their healthy counterparts $(P<0.05)$. The level of WBC was, however, significantly higher in patients with HbSS VOC among the SCD patients $(P<0.001)$. Levels of Hb, RBC, and hematocrit were significantly higher in the controls $(P<0.001)$. There was no significant difference in mean cell $\mathrm{Hb}$ among male patients with $\operatorname{SCD}(P=0.274)$ and female patients with $\operatorname{SCD}(P=0.5410)$. Conclusion: The SCD patients had lower $\mathrm{Hb}$ and RBC than the controls; however, higher PLT and WBC are noted in various status of SCD, possibly reflecting spleen effect in these patients. Further studies are needed to confirm these findings.

Keywords: sickle cell disease, hematological parameters, full blood count, anemia, Ghana

\section{Introduction}

Sickle cell disease (SCD) is the most common inherited disease in Africa, which leads to public health issues at places with populations of African ancestry or descent. ${ }^{1}$ It is a major cause of morbidity and mortality in Africa. ${ }^{2}$ Two percent of all births in Ghana are born with SCD. ${ }^{3}$ The disease refers to varied genetic disorders associated with structurally abnormal hemoglobin $(\mathrm{Hb})$, which results in the episodic formation of sickle-shaped red blood cells (RBCs) and several clinical manifestations. ${ }^{4}$ The common characteristic features in the pathophysiology of SCD are vaso-occlusion and chronic hemolytic anemia. ${ }^{5} \mathrm{SCD}$ is often characterized by marked inflammation, leukocytosis, leukocyte activation, and potentially increased leukocyte adhering to the vascular endothelium. ${ }^{6}$ This leukocyte adhesion to the endothelium could itself promote vaso-occlusion, ${ }^{7}$ which is the hallmark of $\mathrm{SCD} .{ }^{4}$ 
A previous report indicated that SCD patients have elevated white blood cell (WBC) counts, ${ }^{6,8,9}$ activated granulocytes, monocytes, and endothelial cells, enhanced expression of endothelial cell adhesion molecules, elevated cytokine levels and elevated acute-phase reactants. ${ }^{7}$ Moreover, another study has reported that the use of drugs, such as Hydroxyurea, lowers WBC count and thus improves the clinical outcome of SCD patients. ${ }^{10}$ Anemia, which is generally observed in SCD patients, is a reflection of an overall severity of SCD. ${ }^{11}$ While higher counts or values of $\mathrm{Hb}$ are linked with higher rates of severe pain in SCD patients, ${ }^{12}$ lower steady-state $\mathrm{Hb}$ usually accounts for higher risk of stroke in these same patients. ${ }^{11}$ Previous reports have demonstrated that high leukocyte count appears to be a risk factor for several severe complications of SCD, such as rates of severe pain, ${ }^{12}$ acute chest syndrome, ${ }^{13}$ and mortality. ${ }^{14}$ The study by Balkaran et $\mathrm{al}^{15}$ established an association of increased WBC with cerebrovascular accident. Another study among SCD children in Nigeria reported that leukocytosis and neutrophilia are related to disease severity. ${ }^{16}$ The hematological profile of Ghanaian SCD patients has not been studied extensively in recent years. Findings from such work may provide a predictive data of SCD patients' hematological parameters in Ghana as well as contribute to the improvement of SCD management. The current study aimed at determining hematological parameters among SCD patients with vaso-occlusion, those in the steady state as well as healthy controls at a teaching hospital in Ghana.

\section{Materials and methods}

The study was conducted at the Korle Bu Teaching Hospital (KBTH), Accra, Ghana after the study protocol was approved by the Ethical and Protocol Review Committee of University of Ghana Medical School. Written informed consents were obtained from subjects. Consent was also sought from the parents/guardians of the children recruited into the study by signing a written informed consent agreement. The study involved 628 male and female HbSS and HbSC SCD patients in vaso-occlusive crises (VOC) and steady states receiving care at the Center for Clinical Genetics (Sickle Cell Clinic) and healthy HbAA controls, from February 2013 to May 2015. This clinic attends to sickle cell individuals aged 13 years and above. The control group (HbAA) was recruited from voluntary blood donors at the Accra Area Blood Center for National blood transfusion at the KorleBu Teaching Hospital, Accra, who consented to participate in the study. An established laboratory diagnosis of SCD was necessary for eligibility for enrollment. Steady state was clinically defined as a patient who has been well and has not been in crisis for at least 2 weeks. ${ }^{17}$ Vaso-occlusive crisis was clinically defined as pains in the bones, muscles, and joints not attributable to any other cause and requiring parenteral analgesia and hospitalization at the Center for some hours. ${ }^{17}$ Patients with other conditions that may affect hematological indices such as renal failure, pregnancy, and recent blood transfusion 3 months prior to the study were excluded from the study. ${ }^{2}$ Five milliliters of venous blood sample was collected from the antecubital veins of participants by venepuncture into EDTA tubes. Samples were thoroughly mixed to prevent cell lysis and coagulation. A full blood count (FBC) was done within 2 hours of collection using labsystem Multiskan MS (Amisham Bioscience Ltd., Chalfont, UK). This is a three-part autoanalyzer which runs 19 parameters per sample including $\mathrm{Hb}$ concentration, packed cell volume, RBC concentration, mean corpuscular $\mathrm{Hb}$, mean cell volume, mean corpuscular $\mathrm{Hb}$ concentration, WBCs, and platelet (PLT) parameters.

\section{Statistical analysis}

The data were entered into SPSS version-20 software. Frequency tables were generated for nominal and ordinal variables. The results were expressed as mean \pm SD. Student's $t$-test was used to compare means differences between males and females. ANOVA with a Bonferroni post hoc test was used to compare the values between more than two groups. Statistical significance was considered at $P<0.05$.

\section{Results}

\section{Characteristics of study subjects}

A total of 628 subjects were recruited for this study. This was made up of $148 \mathrm{HbAA}$ controls (93 males, 55 females) with a mean age of $31.9 \pm 10.0$ years, $208 \mathrm{HbSS}$ patients in steady state (110 males, 98 females) with a mean age of 25.5 \pm 9.7 years, $82 \mathrm{HbSC}$ patients in steady state ( 30 males, 52 females) with a mean age of $34.9 \pm 14.1$ years, $156 \mathrm{HbSS}$ patients in VOC (64 males, 92 females) with a mean age of 26.2 \pm 9.4 years, and $34 \mathrm{HbSC}$ patients in VOC (12 males, 22 females) with a mean age of $32.4 \pm 12.0$ years.

\section{Hematological parameters of male and female HbSS in steady state}

Females had significantly higher mean cell volume (MCV; $P=0.0411)$, mean cell hemoglobin ( $\mathrm{MCH} ; P=0.0145)$, and mean cell hemoglobin concentration (MCHC; $P=0.0205$ ) than males in steady state; however, red cell distribution width (RDW; $P=0.0431)$ and WBC counts $(P=0.0016)$ were significantly higher in males compared with females. The mean differences in $\mathrm{Hb}$, hematocrit (HCT), RBC, mean 
platelet volume (MPV), platelet distribution width (PDW), platelet (PLT) count, and plateletcrit (PCT) were not significant between males and females $(P>0.05$; Table 1$)$.

\section{Hematological parameters of male and female HbSS in VOC}

There were significantly lower $\mathrm{Hb}(P=0.0035)$, HCT $(P=0.0034), \operatorname{RBC}(P=0.0015), \mathrm{RDW}(P=0.0048)$, and WBC $(P=0.0012)$ in females than males except MCV $(P<0.001)$. However, the mean differences in MPV, MCV, MCH, MCHC, PDW, PLT, and PCT were not significant $(P>0.05)$ between both genders in VOC (Table 2).

\section{Hematological parameters of male and female HbSC in steady state}

There were significantly lower $\mathrm{Hb}(P \leq 0.001)$, HCT $(P<0.001)$, RBC $(P=0.0001)$, and PDW $(P=0.0117)$ in females than males except $\operatorname{WBC}(P=0.0219)$ in steady state (Table 3). In VOC, differences in means of hematological parameters were not significant $(P>0.05)$ between males and females (Table 3).

\section{A comparison of hematological}

parameters between healthy controls, $\mathrm{HbSS}$, and $\mathrm{HbSC}$ male patients with sickle cell disease in steady state and in VOC

The mean $\mathrm{Hb}, \mathrm{HCT}, \mathrm{RBC}, \mathrm{MCHC}$, RDW, and MPV were significantly higher in HbAA than in $\mathrm{HbSS}$ and $\mathrm{HbSC}$ in steady state and VOC $(P<0.001)$. However, PLT, PCT, and

Table I Hematological parameters of male and female HbSS patients in steady state

\begin{tabular}{|c|c|c|c|}
\hline Parameters & $\begin{array}{l}\text { Male }(n=I \mid 0) \\
(\operatorname{mean} \pm S D)\end{array}$ & $\begin{array}{l}\text { Female }(n=98) \\
(\text { mean } \pm S D)\end{array}$ & $P$-value \\
\hline $\mathrm{Hb}(\mathrm{g} / \mathrm{dL})$ & $8.53 \pm 1.61$ & $8.31 \pm 1.57$ & 0.3128 \\
\hline HCT (\%) & $25.82 \pm 5.15$ & $24.84 \pm 5.18$ & 0.1705 \\
\hline $\mathrm{RBC}\left(10^{6} / \mathrm{mm}^{3}\right)$ & $3.06 \pm 0.71$ & $2.89 \pm 0.77$ & 0.0892 \\
\hline $\operatorname{MCV}\left(\mu \mathrm{m}^{3}\right)$ & $84.97 \pm 8.47$ & $87.44 \pm 8.83$ & $0.04 I I^{*}$ \\
\hline $\mathrm{MCH}(\mathrm{pg})$ & $28.20 \pm 3.5 \mathrm{I}$ & $29.42 \pm 3.60$ & $0.0145^{*}$ \\
\hline $\mathrm{MCHC}(\mathrm{g} / \mathrm{dL})$ & $33.12 \pm 1.46$ & $33.59 \pm 1.44$ & $0.0205^{*}$ \\
\hline RDW (\%) & $18.56 \pm 2.54$ & $17.82 \pm 2.68$ & $0.0431^{*}$ \\
\hline $\operatorname{MPV}\left(\mu \mathrm{m}^{3}\right)$ & $7.47 \pm 0.69$ & $7.32 \pm 0.70$ & 0.1197 \\
\hline PDW (\%) & $13.92 \pm 2.26$ & $14.10 \pm 1.96$ & 0.5275 \\
\hline $\operatorname{PLT}\left(10^{3} / \mathrm{mm}^{3}\right)$ & $466.33 \pm 121.39$ & $461.95 \pm 160.55$ & 0.8236 \\
\hline PCT (\%) & $0.35 \pm 0.10$ & $0.33 \pm 0.11$ & 0.3045 \\
\hline WBC $\left(10^{3} / \mathrm{mm}^{3}\right)$ & $12.18 \pm 3.56$ & $10.69 \pm 3.11$ & $0.0016^{*}$ \\
\hline
\end{tabular}

Note: *Significant.

Abbreviations: $\mathrm{HCT}$, hematocrit; $\mathrm{Hb}$, hemoglobin; $\mathrm{MCH}$, mean cell hemoglobin; MCHC, mean cell hemoglobin concentration; MCV, mean cell volume; MPV, mean platelet volume; PCT, plateletcrit; PDW, platelet distribution width; PLT, platelets; RBC, red blood cell; RDW, red cell distribution width; WBC, white blood cells.
WBC were significantly higher in $\mathrm{HbSS}$ and $\mathrm{HbSC}$ male patients than in HbAA $(P<0.001)$. The mean differences in $\mathrm{MCV}, \mathrm{MCH}$, and PDW were not significant between SCD patients and healthy controls $(P>0.05$; Table 4$)$.

\section{A comparison of hematological parameters between healthy controls, HbSS, and HbSC female patients with sickle cell disease in steady state and in VOC}

The mean Hb, HCT, RBC, MCV, RDW, and MPV were significantly higher in HbAA female patients than in $\mathrm{HbSS}$ and

Table 2 Hematological parameters of male and female HbSS patients in VOC

\begin{tabular}{|l|l|l|l|}
\hline Parameters & $\begin{array}{l}\text { Male (n=64) } \\
(\text { mean } \pm \text { SD) }\end{array}$ & $\begin{array}{l}\text { Female (n=92) } \\
(\text { mean } \pm \text { SD) }\end{array}$ & P-value \\
\hline $\mathrm{Hb}(\mathrm{g} / \mathrm{dL})$ & $9.24 \pm 1.67$ & $8.42 \pm 1.68$ & $0.0035^{*}$ \\
$\mathrm{HCT}(\%)$ & $28.37 \pm 6.01$ & $25.58 \pm 5.74$ & $0.0034^{*}$ \\
$\mathrm{RBC}\left(10^{6} / \mathrm{mm}^{3}\right)$ & $3.50 \pm 0.89$ & $3.05 \pm 0.87$ & $0.0015^{*}$ \\
$\mathrm{MCV}\left(\mu \mathrm{m}^{3}\right)$ & $82.59 \pm 9.45$ & $85.50 \pm 9.45$ & $<0.001^{*}$ \\
$\mathrm{MCH}(\mathrm{pg})$ & $27.50 \pm 6.95$ & $28.40 \pm 4.02$ & 0.3078 \\
$\mathrm{MCHC}(\mathrm{g} / \mathrm{dL})$ & $33.03 \pm 4.92$ & $33.11 \pm 1.69$ & 0.8848 \\
$\mathrm{RDW}(\%)$ & $18.56 \pm 2.89$ & $17.39 \pm 2.20$ & $0.0048^{*}$ \\
$\mathrm{MPV}\left(\mu \mathrm{m}^{3}\right)$ & $7.65 \pm 0.81$ & $7.62 \pm 0.70$ & 0.8213 \\
PDW $(\%)$ & $13.19 \pm 3.01$ & $13.53 \pm 2.74$ & 0.4707 \\
PLT $\left(10^{3} / \mathrm{mm}^{3}\right)$ & $439.34 \pm 158.77$ & $459.09 \pm 193.64$ & 0.5019 \\
PCT $(\%)$ & $0.34 \pm 0.12$ & $0.35 \pm 0.14$ & 0.6394 \\
WBC $\left(10^{3} / \mathrm{mm}^{3}\right)$ & $16.24 \pm 7.37$ & $13.01 \pm 4.83$ & $0.0012^{*}$ \\
\hline
\end{tabular}

Note: *Significant.

Abbreviations: $\mathrm{HCT}$, hematocrit; $\mathrm{Hb}$, hemoglobin; $\mathrm{MCH}$, mean cell hemoglobin; $\mathrm{MCHC}$, mean cell hemoglobin concentration; MCV, mean cell volume; MPV, mean platelet volume; PCT, plateletcrit; PDW, platelet distribution width; PLT, platelets; $\mathrm{RBC}$, red blood cell; RDW, red cell distribution width; WBC, white blood cells; VOC, vaso-occlusive crises.

Table 3 Hematological parameters of male and female HbSC patients in steady state

\begin{tabular}{|c|c|c|c|}
\hline Parameters & $\begin{array}{l}\text { Male }(n=30) \\
(\text { mean } \pm S D)\end{array}$ & $\begin{array}{l}\text { Female }(n=52) \\
(\text { mean } \pm \text { SD })\end{array}$ & $P$-value \\
\hline $\mathrm{Hb}(\mathrm{g} / \mathrm{dL})$ & $12.51 \pm 1.33$ & $10.74 \pm 1.73$ & $<0.00 I^{*}$ \\
\hline HCT (\%) & $39.83 \pm 4.63$ & $33.02 \pm 7.08$ & $<0.00 I^{*}$ \\
\hline $\mathrm{RBC}\left(10^{6} / \mathrm{mm}^{3}\right)$ & $4.82 \pm 0.49$ & $4.04 \pm 0.94$ & $0.000 I^{*}$ \\
\hline $\operatorname{MCV}\left(\mu \mathrm{m}^{3}\right)$ & $82.90 \pm 5.15$ & $81.96 \pm 8.53$ & 0.5860 \\
\hline $\mathrm{MCH}(\mathrm{pg})$ & $26.02 \pm 1.83$ & $26.61 \pm 2.26$ & 0.4225 \\
\hline $\mathrm{MCHC}(\mathrm{g} / \mathrm{dL})$ & $30.02 \pm 1.83$ & $31.86 \pm 1.15$ & 0.308 \\
\hline RDW (\%) & $14.97 \pm 1.35$ & $15.01 \pm 2.58$ & 0.9367 \\
\hline $\operatorname{MPV}\left(\mu \mathrm{m}^{3}\right)$ & $8.32 \pm 1.01$ & $8.23 \pm 1.01$ & 0.9657 \\
\hline PDW (\%) & $14.23 \pm 2.23$ & $12.66 \pm 2.89$ & $0.0117^{*}$ \\
\hline $\operatorname{PLT}\left(10^{3} / \mathrm{mm}^{3}\right)$ & $289.64 \pm 18.31$ & $322.87 \pm 20.70$ & 0.2492 \\
\hline PCT (\%) & $0.23 \pm 0.08$ & $0.26 \pm 0.09$ & 0.1980 \\
\hline WBC $\left(10^{3} / \mathrm{mm}^{3}\right)$ & $6.87 \pm 1.77$ & $9.32 \pm 2.56$ & $0.0219^{*}$ \\
\hline
\end{tabular}

Note: *Significant.

Abbreviations: $\mathrm{HCT}$, hematocrit; $\mathrm{Hb}$, hemoglobin; $\mathrm{MCH}$, mean cell hemoglobin; MCHC, mean cell hemoglobin concentration; MCV, mean cell volume; MPV, mean platelet volume; PCT, plateletcrit; PDW, platelet distribution width; PLT, platelets; $\mathrm{RBC}$, red blood cell; RDW, red cell distribution width; WBC, white blood cells. 
HbSC patients in steady state and VOC $(P<0.001)$. However, PLT, PCT, and WBC were significantly higher in the HbSS and $\mathrm{HbSC}$ females in VOC and steady state than the controls $(P<0.001)$. The mean differences in $\mathrm{MCH}$ and MCHC were not significant between the SCD patients and healthy controls $(P>0.05$; Table 5).

\section{Discussion}

Hematological features and clinical severity of SCD are influenced by gender, genetic, and environmental factors. The presence of $\alpha$-thalassemia, variation in $\mathrm{Hb} F$ level, and the specific haplotype background that is linked to the $\beta$ globin gene play an important role in the severity of disease. ${ }^{18}$ This study highlights the association of hematological parameters with SCD vaso-occlusion in Ghana. Several reports indicate that changes in hematological parameters may account for clinical complications observed in patients with SCD. ${ }^{10,12,15}$ Therefore, good management of SCD can be achieved when hematological parameters are regularly evaluated and the causes for the changes in the hematological parameters rectified.

As expected, it was observed that WBC and PLT counts were generally higher in SCD patients compared with their

Table $4 \mathrm{~A}$ comparison of hematological parameters between healthy controls, HbSS, and HbSC male patients with sickle cell disease in steady state and in VOC

\begin{tabular}{|c|c|c|c|c|c|c|}
\hline Parameters & $\begin{array}{l}\text { Control } \\
(n=93) \\
(m e a n \pm S D)\end{array}$ & $\begin{array}{l}\text { HbSS steady } \\
\text { state }(n=I \mid 0) \\
(\text { mean } \pm S D)\end{array}$ & $\begin{array}{l}\text { HbSC steady } \\
\text { state }(n=30) \\
(\text { mean } \pm S D)\end{array}$ & $\begin{array}{l}\text { HbSS VOC } \\
(n=64) \\
(\text { mean } \pm S D)\end{array}$ & $\begin{array}{l}\text { HbSC VOC } \\
(n=I 2) \\
(\text { mean } \pm S D)\end{array}$ & $P$-value \\
\hline $\mathrm{Hb}(\mathrm{g} / \mathrm{dL})$ & $15.38 \pm 3.68$ & $8.53 \pm 1.61$ & $12.51 \pm 1.33$ & $9.24 \pm 1.67$ & $12.10 \pm 1.63$ & $<0.00 I^{*}$ \\
\hline HCT (\%) & $42.20 \pm 6.5 \mathrm{I}$ & $25.82 \pm 5.15$ & $39.83 \pm 4.63$ & $28.37 \pm 6.01$ & $38.35 \pm 4.37$ & $<0.001^{*}$ \\
\hline $\mathrm{RBC}\left(10^{6} / \mathrm{mm}^{3}\right)$ & $5.14 \pm 0.82$ & $3.06 \pm 0.71$ & $4.82 \pm 0.49$ & $3.50 \pm 0.89$ & $4.45 \pm 0.53$ & $<0.001^{*}$ \\
\hline $\operatorname{MCV}\left(\mu \mathrm{m}^{3}\right)$ & $82.62 \pm 6.09$ & $84.97 \pm 8.47$ & $82.90 \pm 5.15$ & $82.59 \pm 9.45$ & $84.42 \pm 6.20$ & 0.185 \\
\hline $\mathrm{MCH}(\mathrm{pg})$ & $27.44 \pm 2.67$ & $28.20 \pm 3.51$ & $26.02 \pm 1.83$ & $27.50 \pm 6.95$ & $27.20 \pm 2.04$ & 0.274 \\
\hline $\mathrm{MCHC}(\mathrm{g} / \mathrm{dL})$ & $33.18 \pm 1.36$ & $33.12 \pm 1.46$ & $30.02 \pm 1.83$ & $33.03 \pm 4.92$ & $32.24 \pm 0.58$ & $<0.00 I^{*}$ \\
\hline RDW (\%) & $18.91 \pm 13.25$ & $18.56 \pm 2.54$ & $14.97 \pm 1.35$ & $18.56 \pm 2.89$ & $15.43 \pm 1.16$ & $<0.00 I^{*}$ \\
\hline $\operatorname{MPV}\left(\mu \mathrm{m}^{3}\right)$ & $9.09 \pm 1.38$ & $7.47 \pm 0.69$ & $8.32 \pm 1.01$ & $7.65 \pm 0.81$ & $7.88 \pm 0.77$ & $<0.001^{*}$ \\
\hline PDW (\%) & $13.76 \pm 1.92$ & $13.92 \pm 2.26$ & $14.23 \pm 2.23$ & $13.19 \pm 3.0 \mid$ & $13.42 \pm 2.22$ & 0.0900 \\
\hline $\operatorname{PLT}\left(10^{3} / \mathrm{mm}^{3}\right)$ & $224.22 \pm 61.17$ & $466.33 \pm 121.39$ & $289.64 \pm|8.3|$ & $439.34 \pm 158.77$ & $238.56 \pm 109.94$ & $<0.001^{*}$ \\
\hline РCT (\%) & $0.18 \pm 0.07$ & $0.35 \pm 0.10$ & $0.23 \pm 0.08$ & $0.34 \pm 0.12$ & $0.19 \pm 0.07$ & $<0.00 I^{*}$ \\
\hline $\operatorname{WBC}\left(10^{3} / \mathrm{mm}^{3}\right)$ & $5.3 \mathrm{I} \pm \mathrm{I} . \mathrm{II}$ & $12.18 \pm 3.56$ & $6.87 \pm 1.77$ & $16.24 \pm 7.37$ & $9.78 \pm 2.09$ & $<0.001^{*}$ \\
\hline
\end{tabular}

Note: *Significant.

Abbreviations: $\mathrm{HCT}$, hematocrit; $\mathrm{Hb}$, hemoglobin; $\mathrm{MCH}$, mean cell hemoglobin; $\mathrm{MCHC}$, mean cell hemoglobin concentration; MCV, mean cell volume; MPV, mean platelet volume; PCT, plateletcrit; PDW, platelet distribution width; PLT, platelets; RBC, red blood cell; RDW, red cell distribution width; VOC, vaso-occlusive crises; WBC, white blood cells.

Table 5 A comparison of hematological parameters between healthy controls, HbSS, and $\mathrm{HbSC}$ female patients with sickle cell disease in steady state and in VOC

\begin{tabular}{|c|c|c|c|c|c|c|}
\hline Parameters & $\begin{array}{l}\text { Control } \\
(n=93) \\
(\text { mean } \pm S D)\end{array}$ & $\begin{array}{l}\text { HbSS steady } \\
\text { state }(n=I 10) \\
(\text { mean } \pm S D)\end{array}$ & $\begin{array}{l}\text { HbSC steady } \\
\text { state }(n=30) \\
(\text { mean } \pm S D)\end{array}$ & $\begin{array}{l}\text { HbSS VOC } \\
(n=64) \\
(\text { mean } \pm S D)\end{array}$ & $\begin{array}{l}\text { HbSC VOC } \\
(n=I 2) \\
(\text { mean } \pm S D)\end{array}$ & $P$-value \\
\hline $\mathrm{Hb}(\mathrm{g} / \mathrm{dL})$ & $13.19 \pm 3.32$ & $8.31 \pm 1.57$ & $10.74 \pm 1.73$ & $8.42 \pm 1.68$ & $11.26 \pm 1.50$ & $<0.001^{*}$ \\
\hline HCT (\%) & $40.91 \pm 10.94$ & $24.84 \pm 5.18$ & $33.02 \pm 7.08$ & $25.58 \pm 5.74$ & $35.2 I \pm 4.66$ & $<0.001^{*}$ \\
\hline $\mathrm{RBC}\left(10^{6} / \mathrm{mm}^{3}\right)$ & $4.97 \pm 1.26$ & $2.89 \pm 0.77$ & $4.04 \pm 0.94$ & $3.05 \pm 0.87$ & $4.28 \pm 0.56$ & $<0.001^{*}$ \\
\hline $\operatorname{MCV}\left(\mu \mathrm{m}^{3}\right)$ & $82.62 \pm 5.29$ & $87.44 \pm 8.83$ & $81.96 \pm 8.53$ & $85.50 \pm 9.45$ & $82.50 \pm 7.61$ & $<0.001^{*}$ \\
\hline $\mathrm{MCH}(\mathrm{pg})$ & $26.68 \pm 2.05$ & $29.42 \pm 3.60$ & $26.6 I \pm 2.26$ & $28.40 \pm 4.02$ & $26.43 \pm 2.87$ & 0.5410 \\
\hline $\mathrm{MCHC}(\mathrm{g} / \mathrm{dL})$ & $32.29 \pm 0.90$ & $33.59 \pm 1.44$ & $31.86 \pm 1.15$ & $33.11 \pm 1.69$ & $31.96 \pm 1.03$ & 0.4588 \\
\hline RDW (\%) & $18.59 \pm 13.25$ & $17.82 \pm 2.68$ & $15.01 \pm 2.58$ & $17.39 \pm 2.20$ & $14.86 \pm 1.16$ & $<0.001^{*}$ \\
\hline $\operatorname{MPV}\left(\mu \mathrm{m}^{3}\right)$ & $8.15 \pm 1.08$ & $7.32 \pm 0.70$ & $8.23 \pm 1.01$ & $7.62 \pm 0.70$ & $7.94 \pm 0.78$ & $<0.001^{*}$ \\
\hline PDW (\%) & $14.91 \pm 1.970$ & $14.10 \pm 1.95$ & $12.66 \pm 2.89$ & $13.53 \pm 2.74$ & $12.79 \pm 2.22$ & $<0.001^{*}$ \\
\hline $\operatorname{PLT}\left(10^{3} / \mathrm{mm}^{3}\right)$ & $250.82 \pm 80.77$ & $461.95 \pm 160.55$ & $322.87 \pm 20.70$ & $459.09 \pm 193.64$ & $319.00 \pm 114.88$ & $<0.001^{*}$ \\
\hline РCT (\%) & $0.19 \pm 0.06$ & $0.33 \pm 0.11$ & $0.26 \pm 0.09$ & $0.35 \pm 0.14$ & $0.25 \pm 0.08$ & $<0.001^{*}$ \\
\hline WBC $\left(10^{3} / \mathrm{mm}^{3}\right)$ & $5.793 \pm 1.28$ & $10.69 \pm 3.11$ & $9.32 \pm 2.56$ & $|3.0| \pm 4.83$ & $8.25 \pm 1.52$ & $<0.001^{*}$ \\
\hline
\end{tabular}

Note: *Significant.

Abbreviations: $\mathrm{HCT}$, hematocrit; $\mathrm{Hb}$, hemoglobin; $\mathrm{MCH}$, mean cell hemoglobin; $\mathrm{MCHC}$, mean cell hemoglobin concentration; MCV, mean cell volume; $\mathrm{MPV}$, mean platelet volume; PCT, plateletcrit; PDW, platelet distribution width; PLT, platelets; RBC, red blood cell; RDW, red cell distribution width; VOC, vaso-occlusive crises; WBC, white blood cells. 
healthy counterparts. A similar study in Ghana reported elevated levels of PLTs among SCD patients. ${ }^{19}$ Elevated WBC has been linked with SCD patients in previous studies. ${ }^{2,6}$ Therefore, WBC and PLT counts are expected to increase in all patients who may present with any form of complication associated with $\mathrm{SCD},{ }^{2}$ as observed in the current study. In particular, a significant part of this study was the inclusion of patients with VOC (HbSS VOC and HbSC VOC), which is the hallmark of SCD, as well as the greater sample size of subjects. The higher PLT count seen in patients with SCD could be attributed to a possible splenic sequestration, reduction or absence of spleen resulting from hyposplenism in $\mathrm{SCD}^{20}$ or autosplenectomy, ${ }^{6}$ as well as the underlying chronic inflammation. Reports indicate that, there is a correlation between PLT count and SCD, ${ }^{21,22}$ which corroborates the higher counts of PLTs among SCD patients in this study, although a correlation was not determined in this study.

Findings from the current study on increased steady PLT count in SCD patients agree with the work of Freedman and Karpatkin $^{23}$ who followed eight adult SCD patients over a period of 6 months and found an elevation in steady-state PLT counts. Omoti, ${ }^{2}$ in his study, also recorded high PLT counts among SCD patients with vaso-occlusion as well as those in the steady state. Although WBC counts were generally elevated in SCD patients, it is worth noting that the difference in counts was significantly higher in patients with HbSS VOC. Therefore, as the condition of SCD progresses from mild to severe with hemolysis, an elevated WBC count is expected in such patients. ${ }^{24,25}$ Asymptomatic bacteriuria is known in SCD patients in Ghana, compared with their healthy counterparts. ${ }^{26}$ Several reports indicate that high WBC counts usually observed in SCD population are mainly due to bacterial infections..$^{8,9,27-29}$ The current study, however, did not establish a relationship between bacterial infections and WBC counts among the SCD patients. The results from this study revealed that people with the severer form of the SCD have higher counts of WBC and PLTs. Even with larger sample size, the current findings are similar to other results obtained elsewhere. It is interesting that among the SCD patients, WBC and PLT counts were higher in males. Thus, gender may, in part, play a role in levels of WBC and PLTs in SCD patients.

One of the characteristic features in the pathophysiology of SCD is chronic hemolytic anemia. ${ }^{5}$ In SCD, there is an increased tendency for RBC lysis and adhesion. ${ }^{30}$ Total $\mathrm{Hb}$ level vary in SCA patients according to the $\beta$ S haplotypes. ${ }^{18}$ The lower levels of $\mathrm{Hb}$ and HCT among SCD patients in the current study agree with the work of Tshilolo et $\mathrm{al}^{31}$ and Omoti. ${ }^{2}$ Chronic hemolysis, ${ }^{32}$ shortened red cell survival, ${ }^{33}$ as well as low erythropoietin response ${ }^{34}$ associated with SCD might have been involved in the reduced $\mathrm{Hb}$ and HCT levels observed in the present study. The Hb levels in this study are similar to the finding of Nagose and Rathod. ${ }^{35}$ The ongoing chronic hemolytic anemia in the patients may explain the reduced RBC counts observed in the current study. A lower $\mathrm{Hb}$ level in SCD patients with complication (a positive history of leg ulcers) has been reported in a previous study. ${ }^{36}$

Although vaso-occlusion is known to be a complication of SCD, the Hb level was observed to be higher, compared with those at the steady state. The higher levels of $\mathrm{Hb}$ in these patients could, in part, be related to higher blood viscosity and could further increase VOC. A study conducted by Omoti ${ }^{2}$ among SCD patients with VOC and those at the steady state found higher levels of $\mathrm{Hb}$ in patients with $\mathrm{VOC}$, although the difference was not significant. As expected, the level of $\mathrm{Hb}$ was lower in SCD patients at the steady state, probably due to a reduced ongoing hemolysis compared with those in crisis. These SCD patients in their steady state might have adapted well to the anemic state.

In line with other studies, the mean MCV was higher in females, among the SCD patients compared with the controls. ${ }^{37-40}$ A study conducted by Nagose and Rathod, ${ }^{35}$ however, found higher MCV in males than females. The difference could possibly be due to the lower sample size of Nagose and Rathod's study. One limitation of this study was the inability to screen for Plasmodium infection, as the presence of Plasmodium parasites may also lead to hemolysis. We also could not gather information on patients treated with hydroxyurea. More studies in other regions of Ghana should be done to validate previous reports and provide a baseline hematological profile and what to do in the form of an algorithm to assist clinicians in the management of SCD patients.

\section{Conclusion}

The present study found elevated levels of WBC and PLT, as well as lower counts of $\mathrm{Hb}, \mathrm{RBC}$, and HCT concurrently among the SCD patients. The cases had lower $\mathrm{Hb}$ and RBC than the control; however, higher PLTs and WBC are noted in various status of SCD, possibly reflecting spleen effect in these patients. These hematological parameters present a more descriptive data on SCD patients in Ghana and may as well provide a useful tool and assist clinicians (in a form of algorithm) in the management of SCD patients in Ghana. 


\section{Acknowledgments}

The authors are thankful to the Office of Research, Innovation and Development (ORID), University of Ghana, and the University of Ghana-Carnegie Next Generation of Academics in Africa Project for funding the research. The authors are also grateful to the staff and patients of the Center for Clinical Genetics (Sickle Cell Clinic) who took part in the study. Also, the authors would like to thank the volunteers who donated blood and consented to take part in the study as control subjects at the Accra Area Blood Center for National Blood Transfusion at the Korle-Bu Teaching Hospital, Accra, Ghana. The research was funded by the ORID, University of Ghana, and the University of Ghana-Carnegie Next Generation of Academics in Africa.

\section{Disclosure}

The authors report no conflicts of interest in this work.

\section{References}

1. Roberts I, de Montalembert M. Sickle cell disease as a paradigm of immigration hematology: new challenges for hematologists in Europe. Haematologica. 2007;92(7):865-871.

2. Omoti CE. Haematological values in sickle cell anemia in steady state and during vaso-occlusive crisis in Benin City, Nigeria. Ann Afr Med. 2005;4(2):62-67.

3. Baah ATD, Azumah DE, Ampiah C, Boampong J, Nuvor SV. Incidence of human immunodeficiency virus in sickle cell patients in the Cape Coast Metropolis, Ghana. World J AIDS. 2014;4(3):338-345.

4. Stuart MJ, Nagel RL. Sickle-cell disease. Lancet. 2004;364(9442): $1343-1360$

5. Kato GJ, Gladwin MT, Steinberg MH. Deconstructing sickle cell disease: reappraisal of the role of hemolysis in the development of clinical subphenotypes. Blood Rev. 2007;21(1):37-47.

6. Okpala I. The intriguing contribution of white blood cells to sickle cell disease: a red cell disorder. Blood Rev. 2004;18(1):65-73.

7. Brittain JE, Parise LV. Cytokines and plasma factors in sickle cell disease. Curr Opin Hematol. 2007;14(5):438-443.

8. Ahmed SG, Ibrahim UA, Hassan AW. Hematological parameters in sickle cell anemia patients with and without priapism. Ann Saudi Med. 2006;26(6):439-443.

9. Ahmed AE, Ali YZ, Al-Suliman AM, et al. The prevalence of abnormal leukocyte count, and its predisposing factors, in patients with sickle cell disease in Saudi Arabia. J Blood Med. 2017;8:185-191.

10. Zimmerman SA, Schultz WH, Davis JS, et al. Sustained long-term hematologic efficacy of hydroxyurea at maximum tolerated dose in children with sickle cell disease. Blood. 2004;103(6):2039-2045.

11. Ohene-Frempong K, Weiner SJ, Sleeper LA, et al. Cerebrovascular accidents in sickle cell disease: rates and risk factors. Blood. 1998;91(1):288-294.

12. Platt OS, Thorington BD, Brambilla DJ, et al. Pain in sickle cell disease. Rates and risk factors. N Engl J Med. 1991;325(1):11-16.

13. Castro O, Brambilla DJ, Thorington B, et al. The acute chest syndrome in sickle cell disease: incidence and risk factors. The Cooperative Study of Sickle Cell Disease. Blood. 1994;84(2):643-649.

14. Platt OS, Brambilla DJ, Rosse WF, et al. Mortality in sickle cell disease. Life expectancy and risk factors for early death. $N$ Engl J Med. 1994;330(23):1639-1644.
15. Balkaran B, Char G, Morris JS, et al. Stroke in a cohort of patients with homozygous sickle cell disease. J Pediatr. 1992;120(3):360-366.

16. Ademola AS, Kuti BP. Evaluation of clinical severity of sickle cell anemia in Nigerian children. J Appl Hematol. 2013;4(2):58-64.

17. Antwi-Boasiako C, Frimpong $\mathrm{E}$, Ababio GK. The role of nitric oxide in vaso-occlusive crisis in sickle cell disease patients in Ghana. Donnish J Med Med Sci. 2015;2(4):52-55.

18. Oner C, Dimovski AJ, Olivieri NF, et al. Beta S haplotypes in various world populations. Hum Genet. 1992;89(1):99-104.

19. Vercellotti GM. PlGF: a link between inflammation and angiogenesis in sickle disease. Blood. 2003;102(4):1153.

20. de Franceschi L, Cappellini MD, Olivieri O. Thrombosis and sickle cell disease. Semin Thromb Hemost. 2011;37(3):226-236.

21. Kenny MW, George AJ, Stuart J. Platelet hyperactivity in sicklecell disease: a consequence of hyposplenism. J Clin Pathol. 1980;33(7):622-625.

22. Francis RB. Platelets, coagulation, and fibrinolysis in sickle cell disease: their possible role in vascular occlusion. Blood Coagul Fibrinolysis. 1991;2(2):341-353.

23. Freedman ML, Karpatkin S. Elevated platelet count and megathrombocyte number in sickle cell anemia. Blood. 1975;46(4):579-582.

24. Krishnan S, Setty Y, Betal SG, et al. Increased levels of the inflammatory biomarker C-reactive protein at baseline are associated with childhood sickle cell vasocclusive crises. Br J Haematol. 2010;148(5):797-804.

25. Al-Basheer G, Abdelgadir O, Mustafa MEA, Muddathir MRA, Abdelgadir ER. C: reactive protein level and WBC count as biomarkers for vaso-occlusive crisis among patients with sickle cell disease. Am J Med Med Sci. 2015;5(6):283-286.

26. Donkor ES, Osei JA, Anim-Baidoo I, Darkwah S. Risk of asymptomatic bacteriuria among people with sickle cell disease in Accra, Ghana. Diseases. 2017;5(1):4.

27. Buchanan GR, Glader BE. Leucocyte counts in children with sickle cell disease. Comparative values in the steady state, vaso-occlusive crisis and bacterial infection. Am J Dis Chil. 1987;132:396-398.

28. Bagul R, Chandan S, Sane VD, Patil S, Yadav D. Comparative evaluation of C-reactive protein and WBC count in fascial space infections of odontogenic origin. J Maxillofac Oral Surg. 2017;16(2):238-242.

29. Augustina Ii AEF, Marcellinus NU. Some hematological and biochemical changes associated with blood transfusion in sickle cell anaemia patients. J Mol Immunol. 2016;2:1.

30. Embury SH, Hebbel RP, Mohandas N, Steinberg MH. Sickle cell disease: Basic Principles and Clinical Picture. New York: Raven Press. 1994:311-311.

31. Tshilolo L, Wembonyama S, Summa V, Avvisati G. Haemogram findings in Congolese children with sickle cell disease in remission. Med Trop. 2010;70:459-463.

32. Ashutosh L, Elliot PV. Sickle cell disease. In: Hoffbrand AV, Catovsky D, Tuddenham EGD, editors. Postgraduate Haematology. 5th ed. Hoboken: Wiley Blackwell; 2005:104-118.

33. Iheanacho O. Haematological parameters of adult and paediatric subjects with sickle cell disease in steady state, in Benin City, Nigeria. Int Blood Res Rev. 2015;3(4):171-177.

34. Sherwood JB, Goldwesser E, Chilcoat R, et al. Sickle cell anaemia patients have low erythropoietin levels for their degree of anaemia. Blood. 1987;67:46-49.

35. Nagose V, Rathod S. Hematological profile of sickle cell anemia subjects in central India: a cross-sectional analysis. Ann Pathol Lab Med. 2018;5(1):A87-A91.

36. Lamarre Y, Lalanne-Mistrih ML, Romana M, et al. Male gender, increased blood viscosity, body mass index and triglyceride levels are independently associated with systemic relative hypertension in sickle cell anemia. PLoS One. 2013;8(6):e66004.

37. Serjeant GR, Grandison Y, Lowrie Y, et al. The development of haematological changes in homozygous sickle cell disease: a cohort study from birth to 6 years. Br J Haematol. 1981;48(4):533-543. 
38. Diop S, Thiam D, Cisse M, et al. New results in clinical severity of homozygous sickle cell anemia, in Dakar, Senegal. Hematol Cell Ther. 1999;41(5):217-221.

39. Mouélé R, Boukila V, Fourcade V, Feingold J, Galactéros F. Sickle-cell disease in Brazzaville, Congo: genetical, hematological, biochemical and clinical aspects. Acta Haematol. 1999;101(4):178-184.
40. Akodu AK, Tella BA, Olujobi OD. Effect of stabilization exercise on pain and quality of life of patients with non-specific chronic low back pain. A JPARS. 2015;7:7-11.

\section{Publish your work in this journal}

The Journal of Blood Medicine is an international, peer-reviewed, open access, online journal publishing laboratory, experimental and clinical aspects of all aspect pertaining to blood based medicine including but not limited to: Transfusion Medicine; Blood collection, Donor issues, Transmittable diseases, and Blood banking logistics; Immunohematology; Artificial and alternative

\section{Dovepress}

blood based therapeutics; Hematology; Biotechnology/nanotechnology of blood related medicine; Legal aspects of blood medicine; Historical perspectives. The manuscript management system is completely online and includes a very quick and fair peer-review system. Visit http://www.dovepress.com/ testimonials.php to read real quotes from published authors.

Submit your manuscript here: http://www.dovepress.com/journal-of-blood-medicine-journa 